NBER WORKING PAPER SERIES

HISTORY OF AMERICAN CORPORATE GOVERNANCE:
LAW, INSTITUTIONS, AND POLITICS

Eric Hilt

Working Paper 20356

http://www.nber.org/papers/w20356

\author{
NATIONAL BUREAU OF ECONOMIC RESEARCH \\ 1050 Massachusetts Avenue \\ Cambridge, MA 02138 \\ July 2014
}

I would like to thank Carola Frydman, David Robinson, Naomi Lamoreaux, Antoinette Schoar, and Marc Weidenmier for comments. The views expressed herein are those of the author and do not necessarily reflect the views of the National Bureau of Economic Research.

NBER working papers are circulated for discussion and comment purposes. They have not been peerreviewed or been subject to the review by the NBER Board of Directors that accompanies official NBER publications.

(C) 2014 by Eric Hilt. All rights reserved. Short sections of text, not to exceed two paragraphs, may be quoted without explicit permission provided that full credit, including $\odot$ notice, is given to the source. 
History of American Corporate Governance: Law, Institutions, and Politics

Eric Hilt

NBER Working Paper No. 20356

July 2014

JEL No. G3,N21,N81

\begin{abstract}
$\underline{\text { ABSTRACT }}$
This paper presents an overview of the history of corporate governance in the United States, emphasizing the period before the advent of federal securities laws and the Securities and Exchange Commission (SEC). Recent research has overturned many widely accepted beliefs about corporate governance during this period. In particular, the evolution of American corporate governance has not followed a simple, linear trajectory, beginning with small, well-governed firms and ending with large, poorly governed ones. Over time, economic and institutional changes have given rise to successive generations of corporations with their own governance problems and their own mechanisms to address those problems. When existing governance mechanisms failed, the United States experienced corporate governance crises-episodes that shattered investors' faith in corporate management and the legal institutions intended to protect their rights. The resolutions of these crises have sometimes been found in legal innovations, and in other cases, in institutional or market-based solutions.
\end{abstract}

Eric Hilt

Wellesley College

Department of Economics

106 Central Street

Wellesley, MA 02481

and NBER

ehilt@wellesley.edu 


\section{Introduction: History and the American Corporation}

Across the world today, there is a striking relationship between legal institutions and financial development. Countries with legal systems that offer robust protections for minority shareholders have larger equity markets, and firms in those countries make greater use of outside finance (La Porta et al. 1997). The United States in particular offers relatively strong legal protections to investors and possesses deep capital markets. Its corporations' ownership structures are also distinctive: America's public companies are usually not dominated by controlling investors, and in particular family business groups, pyramidal structures, ownership by banks, and dual-class shares that allocate control to minority owners are all uncommon. Widely dispersed ownership is more typical of American public corporations than those of most other countries (La Porta et al. 1999).

When did this distinctive style of corporate ownership, and the legal institutions that support it, emerge in the United States? Did American corporate ownership and governance once resemble those of other countries, or was it always relatively unique? If it evolved over time, what accounts for this evolution? Answers to these questions can help evaluate competing explanations of the ownership patterns of American companies, such as those suggesting that populist politics has restrained financial institutions and large investors (Roe 1994) or that strong legal protections for investors, originating in the common law, have made dispersed ownership possible (La Porta et al. 1998). Moreover, they can shed light on the level and nature of the investor protections offered in the United States when it was an emerging market---which is in some ways the relevant comparison to today's developing countries (see Morck 2011 for an overview).

This article presents an overview of the history of corporate governance in the United States, emphasizing the period before the advent of federal securities laws and the Securities and Exchange Commission (SEC) in the 1930s. The legal and institutional protections of investors, and their evolution, are analyzed, and data on the ownership structures of corporations at different points in time are presented. The discussion emphasizes large, publicly traded corporations, the historical equivalents of the modern enterprises that are the focus of the literature on corporate governance today. The 
ownership data presented include New York Stock Exchange (NYSE)-traded firms in the 1820s, which mostly consisted of banks and insurance companies; Boston Stock Exchange--traded industrials and utilities in the 1870s, when the Boston Stock Exchange was the premier market for industrials in the United States (Atack and Rousseau 1999); and finally, NYSE-traded railroads in 1910, when railroads were the largest American business enterprises.

Until relatively recently, the early history of the corporation in America has been a somewhat neglected subject. In part, this reflects the influence of a literature on the evolution of business enterprise that has mostly ignored issues relating to the law or to the internal governance of corporations (for example, Chandler 1977). But it also reflects the frustrating complexity of early legal history. Corporation law in the United States is state law, and early enterprises could only incorporate in their home states (see Henderson 1918). Studying the history of the corporation requires analyzing many states' early laws, and any existing data on early corporate ownership likely resides in the archives of state governments. The early nineteenth century is a statistical dark age, particularly for business records (David 1967).

Among the literature that does exist on the topic, Berle and Means' (1932) work is the most important and influential. They argue that the separation of ownership from control was a recent development and that that in the early nineteenth century, it had not occurred. Berle and Means (1932, p. 135, footnote 14) claim that for early American corporations, "the number of shareholders was few; they could and did attend meetings; they were business-men; and their vote meant something." They then argue that legal, organizational, and technological developments in the late-nineteenth and earlytwentieth centuries led to the emergence of large, diffusely held enterprises controlled by professional managers or by minority interests. Much of the scholarship on corporate governance that has been produced since Berle and Means has accepted their characterization of the history of American corporations (see, e.g., Dodd 1938, Hovenkamp 1991, and Coffee 2001; an important exception is Werner 1986). But the early history of American corporations has not been well documented, and the arguments of Berle and Means may have been accepted simply because they seemed 
appealing and persuasive in light of what is known about corporate governance in the twentieth century.

Recent years have seen a wave of research on early corporations and their governance that has made use of archival data. ${ }^{1}$ Much of this research has concluded that the Berle and Means view of early corporate governance is simply incorrect: Evidence of substantial governance problems has been found among early American companies. Although the average size of public corporations certainly grew over time, the evolution of American corporate governance has not followed a simple, linear trajectory, beginning with small, well-governed organizations in which shareholders participated actively and eventually ending with large, poorly governed organizations with absentee owners and opportunistic managers.

Over its long history, American corporate governance has been concerned with three interrelated problems (see Lamoreaux 2009). The first, which I term Problem 1, is the familiar managerial incentive problem that arises when ownership is highly diffuse: Control falls into the hands of managers, who may act in self-interested ways. Problem 2 , which is also familiar today, and arises in circumstances where Problem 1 is unlikely to be present, is that of controlling shareholders taking actions that benefit themselves at the expense of minority or outside investors. Finally, Problem 3, which is now far less familiar in the United States, arises from the power of the state to control the creation of corporations or expropriate existing enterprises.

Today, much of the scholarship on corporate governance in the United States is focused on Problem 1 (see, for example, J ensen and Meckling 1976), whereas much of the research on developing country firms is focused on Problem 2 (for example, Bertrand, Mehta and Mullainathan, 2002). But the history presented in this article indicates that Problem 2 and also Problem 3 were significant sources of concern in the United States during the early nineteenth century. Episodes where Problem 1 plagued the governance of some early American corporations also occurred. Over time, economic

\footnotetext{
${ }^{1}$ This work is not confined to the history of the United States (see, e.g., Acheson et al. 2014; Franks, Mayer and Rossi 2009; Freeman, Pearson and Taylor 2012; Guinnane et al. 2007; Hannah 2010; Morck 2005a; and Musacchio 2009).
} 
and institutional changes gave rise to successive generations of corporations with their own governance problems and their own mechanisms to address those problems. When existing governance institutions failed on a large scale, the United States experienced what might be termed corporate governance crises-episodes that shattered investors' faith in corporate management and the legal institutions intended to protect their rights. The resolutions of these crises have sometimes been found in new laws, and in other cases, in institutional or market-based solutions.

Another major theme of the literature on modern corporate governance has been the absence of pyramidal business groups in the United States (Becht and Delong 2005, Villalonga and Amit 2009). It has been argued that the United States once had such groups on a large scale but that the imposition of taxes on intercoporate dividend payments during the New Deal made pyramids unattractive and broke them apart (Morck 2005b). In contrast, this article argues that pyramidal business groups were never important in the United States. They failed to arise on a large scale because historically, wealthy families and important businesses have not felt they were necessary.

\section{Early American Corporations and their Governance}

\subsection{Corporate Ownership in the Early Nineteenth Century}

The earliest existing data on the ownership of a relatively large cross-section of American public companies can be observed is from NYSE-traded companies in the 1820s. By that time, the growing concentration of wealth from trade and finance within New York City made the NYSE the most active market for corporate securities in the United States. The exchange had no formal listing requirements; it simply facilitated trade in shares of corporate stock, as well as in the bonds of the federal, state, and city governments. In 1825 the shares of 67 corporations, mostly those of banks and insurance companies, saw trading. ${ }^{2}$ These firms, whose headquarters were overwhelmingly located on or near Wall Street, were often enormously profitable, partly

\footnotetext{
2 There were 19 banks and 44 insurance companies; the remainder included a water company, a gas company, and two coal companies.
} 
Table 1:

Ownership of NYSE-Traded Firms, 1826

\begin{tabular}{|c|c|c|c|c|c|}
\hline & \multirow[b]{2}{*}{$\begin{array}{c}\text { Total } \\
\text { Shareholders }\end{array}$} & \multicolumn{2}{|c|}{ \% Widely Held: } & \multirow{2}{*}{$\begin{array}{l}\text { \% of Votes: } \\
\text { Shares } \\
\text { Owned } \\
\text { by Directors } \\
\end{array}$} & \multirow{2}{*}{$\begin{array}{c}\text { \% of Votes: } \\
\text { Shares } \\
\text { Controlled by } \\
\text { Directors } \\
\end{array}$} \\
\hline & & $\begin{array}{c}10 \% \\
\text { Cutoff } \\
\end{array}$ & $\begin{array}{l}20 \% \\
\text { Cutoff }\end{array}$ & & \\
\hline & (1) & (2) & (3) & (4) & (5) \\
\hline All NYSE- Listed Companies & 139 & 52 & 75 & 21.7 & 39.6 \\
\hline Above-median capital & 201 & 71 & 94 & 15.9 & 25.2 \\
\hline Median capital or below & 101 & 42 & 65 & 26.0 & 47.4 \\
\hline
\end{tabular}

because of the robust demand for financial services in America's growing economy, but also because the state government tightly rationed access to corporate charters with the power to enter the banking industry, an issue we will analyze below.

Ownership records from this era are extremely scarce, but in the 1820s New York State implemented an unusual capital tax that required all corporations to submit lists of their stockholders to the state government. These were first uncovered and analyzed in Hilt (2008). Table 1 presents ownership data for the companies that were traded on the NYSE in 1826. The mean paid-in capital of these enterprises was $\$ 605,000$, equivalent to $\$ 14.5$ million in 2012 dollars, and the median capital was $\$ 500,000$.

The data in Table 1 indicate that even as far back as 1826-prior to the introduction of virtually any statutory investor protections in the modern sensepublicly traded companies had a wide range of ownership structures, and there were some widely held firms. NYSE-listed companies had on average 139 shareholders, a number that might seem miniscule today, but which nonetheless is consistent with these firms having substantial numbers of owners holding small stakes. Columns 2 and 3 present the rates at which the firms were widely held by the definitions of La Porta et al. (1999). J ust over 50\% were widely held in the sense of not having a $10 \%$ owner; $75 \%$ did not have a $20 \%$ owner. The lower two rows present the ownership of the corporations by size. Those with median capital or above were widely held at rates similar to those of the modern American corporations in the La Porta et al. (1999) dataset. Column 4 of the data presents the percentage of the votes represented by the shares standing in the 
names of the directors. For all firms, this was approximately $20 \%$ and it was approximately $5 \%$ lower than that for the large firms and 5\% higher for the smaller firms.

With regard to the governance of these enterprises, Problem 2 would seem to have been much more likely to be a concern than Problem 1. But in order to analyze the problems these enterprises actually faced, we must first examine the legal rights of early shareholders, and the political context within which they were determined.

\subsection{Early Corporate Charters}

Today, the procedure for incorporating a business in the American states is routine and inexpensive: One simply submits a certificate of incorporation-usually a one-page form - to the secretary of state and pays a nominal fee. The documents that govern the internal relations of the firm are drawn up separately by the incorporators, who have broad freedom to structure their corporation as they wish. In this sense, the formation of a corporation is fundamentally a contracting process among the incorporators, which is simply registered with the state. Businesses can in fact choose to incorporate in any state, irrespective of where their operations are located; approximately $85 \%$ of those incorporating out of state choose Delaware (Bebchuk and Hamdani 2002).

Until the mid- to late-nineteenth century, the process of forming a corporation was radically different. The only procedure for incorporation was to appeal to the state government for a special legislative act: For a business to become a corporation, the state had to pass a law, and the contents of that law-the corporation's charter-were the outcome of a negotiation between the incorporators and the state government. The formation of early corporations was not merely a contracting process among the incorporators; it was also a contract between the incorporators and the state. And the state frequently renegotiated the terms of that contract by granting charters of limited duration and imposing changes or exacting concessions or payments in exchange for renewals. The state also carefully rationed charters in some industries, particularly banking, to raise the value of the charters it granted and thereby enhance the power of the political factions in control of the government (Bodenhorn 2006). Early 
corporations were intimately tied to politics, and Problem 3 was an issue of central concern.

What rights did early corporation law grant to shareholders? In contrast to other areas of the law, the United States did not inherit a well-developed set of judicial precedents or regulatory statutes relating to business corporations from England (Gower 1956, Harris 2000). Although English business corporations were created beginning in the sixteenth century, they were not common, and English corporation law remained in a relatively primitive state at the time of the American Revolution. Among early American corporations, practices that followed tradition rather than law were generally adhered to. On many issues relating to the rights of stockholders or the authority and responsibilities of directors, the law was silent. Were directors obligated to disclose their own transactions with the corporation to the shareholders? To what extent could they engage in self-dealing or utilize the resources of the firm for their own personal gain? Did shares that were borrowed from a broker, or repurchased by the company, or subscribed for but not fully paid-in, entitle their holders to votes? Traditional practices offered answers to each of these questions, but the law did not. Stockholders who felt they had been wronged in such matters might claim they had been the victim of fraud, which is a civil tort at common law, or attempt to hold directors accountable as fiduciaries, a strategy for which there was a strong foundation in English case law (Dodd 1954). But in the early years of the American republic, these strategies were still untested.

Most of the legal rights to which shareholders were entitled were specified in the corporations' charters. Voting in annual meetings was the principal mechanism by which stockholders participated in the governance of corporations, and the charters typically dictated how director elections would be conducted and how the president would be chosen. Although voting in early corporations was relatively similar to modern shareholder voting, one striking difference is that many early charters configured the voting rights of stockholders in a way that enhanced the relative influence of small investors, using what has been termed graduated voting rights. With graduated rights, the votes per share to which an investor was entitled was a decreasing function of the 
number of shares held. ${ }^{3}$ The effect was the opposite of most of today's dual-class shares, which typically increase the voting power of a founding blockholder (Gompers Ishii and Metrick 2010).

Hilt (2008) develops an index of the degree of diminishment of the voting power of large shareholders by graduated voting rights schemes, based on the average level of votes per share across all possible levels of shareholdings. The index increases in the voting power of large blocks of stock, and ranges from approximately 0 for a rule of one vote per shareholder, to 1 for the rule of one vote per share. ${ }^{4}$ In an analysis of all 812 corporate charters granted up to 1825 in New York-the largest and most legally influential state at the time - the average value of this index was 0.63 . It was highest among firms in industries that did not typically seek the participation of small investors, and lowest among firms in industries that did. This is an indication that graduated voting rights were imposed with the intention of helping incorporators address Problem 2 and attract investments from small shareholders. ${ }^{5}$ However, there is some evidence that these schemes were sometimes circumvented by dividing individuals' blocks of shares into small holdings in the names of different family members (Hammond 1957; Dunlavy 2004). This may account for the diminished use of graduated voting rights over the nineteenth century.

Two other elements of early corporate governance are worth noting. The first is dividend payments, which were likely used to address Problem 2. To outside investors,

\footnotetext{
${ }^{3}$ For example, the original 1791 charter of the bank of New York specified that the stockholders were entitled to "one vote for each share not exceeding four, five votes for six shares, six votes for eight shares, seven votes for ten shares, and one vote for every five shares above ten" (Laws of New York, 1791, chapter 37.) Thus an owner of four shares received four votes, but an owner of 20 shares received nine votes, or 0.45 votes per share.

${ }^{4}$ The impact of a graduated voting rights scheme on the voting power of each shareholder depends on the actual distribution of shares; only in the presence of small shareholders does the proportion of votes held by blockholders fall. The index is therefore a measure of the potential of a voting rights configuration to restrict the voting power of large shareholders.

${ }^{5}$ Graduated voting rights originated among early business corporations in England; see Scott (1912). A substantial literature has developed that analyzes the purpose and effects of graduated voting rights in the American context; on their political significance, see Dunlavy $(2004,2006)$; on their effects among nineteenth-century American banks, see Bodenhorn (2014); and see Hansmann and Pargendler (2010) on their effects on consumers. Hilt (2013) presents a synthesis.
} 
the operations and finances of corporations were likely quite opaque, and the extent of self-dealing by insiders may have been impossible to observe. By committing themselves to making regular dividend payments, managers may have signaled to investors that they would not expropriate the assets of the company (see Baskin and Miranti 1997). The second is the composition of the boards. Among the directors of early corporations were many wealthy, prominent, and politically connected men (see Hilt and Valentine 2012), and the names of the directors were well publicized. A board seat likely signaled that such men were willing to stake their own reputations on the business' success, or at least that the managers would operate the firm according to principles suitable to such men. This may also have helped the corporations address Problem 2. However, the political connections of the directors were perhaps even more important. Boards of directors often included sitting officeholders or important figures from political parties. This identified the business with the political forces responsible for its incorporation, and indicated how well the corporation's interests would be represented in the state government, for example by blocking entry by potential competitors, or by renewing the charter on favorable terms when it expired. This helped the corporation address Problem 3.

Finally, it is also likely that the firms relied on what has been termed "informal relations of trust" (Franks, Mayer and Rossi 2009). The ownership of these corporations was predominantly local, which may have facilitated personal contact and trust between investors and the directors and managers.

The mechanisms developed to address the fundamental problems of the governance of early corporations functioned reasonably well under ordinary circumstances. But they were mostly informal and based on tradition, rather than lawand even those that did carry the force of law could be circumvented. When aggressive entrepreneurs who had little patience for those traditions obtained control over several prominent corporations, spectacular governance failures resulted.

\subsection{Breakdown: Wall Street's First Corporate Governance Crisis}

The year 1826 was a tumultuous one in New York. Several of New York's insurance companies, operated by men who were not politically connected enough to obtain a 
bank charter, had defied state law and entered the banking business, issuing banknotelike instruments to finance their lending (see Hilt 2009a). Effectively, their solution to Problem 3 was to act as proto-shadow banks and evade the state's banking statutes and regulations. To do this, the managers of insurance companies engaged in financial transactions that violated tradition, but not necessarily any law. For example, they used the assets of companies they controlled as collateral for loans to acquire other companies, sometimes in their own names. And in cases where their firms held large blocks of stock that had been subscribed for but not paid in, or repurchased by the company from subscribers, the directors voted those shares to perpetuate their control.

Column 5 of Table 1 illustrates the effect of these transactions: Many of the directors controlled, and voted, shares held in the name of other corporations, as well as treasury shares. These holdings often created substantial wedges between the directors' cash-flow rights and their control rights, as in modern pyramidal structures. For 12 of the corporations, the additional votes gave the directors majority control over their corporations.

An economic downturn began in 1825, as a serious financial panic hit England. As the recession spread to New York, stock prices fell, and risk spreads in financial markets widened. In the summer of 1826, a New York newspaper began publishing letters and editorials claiming that the speculators running several insurance companies were utilizing fraudulent transactions among the companies they controlled to meet their growing interest obligations. When one of the most vulnerable of these firms stopped payments on its liabilities, panic broke out, and several large banks and insurance companies faced runs and closed. It was quickly revealed that many of these firms were deeply insolvent and had been so for long periods of time. Insiders had successfully concealed the state of their enterprises by continuously paying substantial dividends, apparently with borrowed money. It was also revealed that several of the wealthiest and most prominent of the directors of the failed corporations had not attended any board meetings in years and had not bothered to even monitor the activities of the other directors. The traditional solutions to governance problems had clearly failed. 
The public was shocked and outraged. New York's district attorney obtained at least six different indictments against the men at the center of the scandals, which resulted in a series of spectacular criminal trials (see Hilt 2009b). More importantly, a wave of litigation initiated by the stockholders and creditors of the failed companies quickly overwhelmed New York's chancery courts. The stockholders of the New York Coal Company, whose capital had been used by its directors as collateral in an unsuccessful attempt to take over City Bank (the predecessor of today's Citibank), successfully argued that minority stockholders had the right to sue directors of a corporation for malfeasance. The court's ruling in the 1832 case Robinson v. Smith became a general principle of equity jurisprudence and established the basis of the shareholder derivative suit (see Boyle 1965). ${ }^{6}$

The state government also responded with sweeping changes to its laws, particularly intended to address issues relating to Problem 2. In 1828, New York enacted a series of detailed statutes that specifically prohibited many of the transactions at the heart of the failures and also imposed financial reporting requirements, prohibited large loans to directors, and created a presumption of fraud, and with it, personal liability for directors and stockholders, in all bankruptcies. (This latter term was quickly found to be too severe, and was repealed.) The provisions also clarified and strengthened the rights of stockholders and creditors to use the court of chancery to seek injunctions against malfeasant directors and place insolvent corporations in the hands of receivers. This legislation was probably the first major investor protection law enacted in any common lawjurisdiction.

New York's experience was extreme, but as corporations proliferated, American state legislatures sought to define the rights of these organizations and their stockholders and creditors through an enormous body of statutes. Many states adopted significant portions of New York's 1828 law (Kehl 1939). As the first treatise on American corporation law noted in 1832 (Angell and Ames 1832, p. 357), "the statute books of many states will show that an opinion has strongly and extensively prevailed

\footnotetext{
${ }^{6}$ This is a suit brought by a shareholder on behalf of a corporation, generally against a controlling insider.
} 
that the common law relative to commercial corporations is not adequate to their proper regulation and government." Gradually, an indigenous corporation law developed in the United States that blended common-law institutions with American innovations. In response to this corporate governance crisis and others like it, more robust mechanisms to address Problem 2 were sought in the form of stronger legal protections for investors.

Over time, reformist political factions in New York and other states attempted to eliminate Problem 3 by adopting general incorporation acts. General acts provided open access to incorporation, replacing the regime of granting charters by special legislative act (see North, Wallis and Weingast 2009). The early versions of these laws often imposed a rigid governance template on the businesses created through their terms, for example requiring a rule of one vote per share and regulating the size of the board. In some cases, this one-size-fits-all approach may have prevented incorporators from having the freedom to adopt their own solutions to Problem 2. That is, the solution found to Problem 3 aggravated other problems (Lamoreaux 2009).

\subsection{Industrial Companies in the Mid-Nineteenth Century: Massachusetts}

The next point at which we can observe corporate ownership is in mid-nineteenthcentury Massachusetts. At the time, that state had the greatest number of business corporations per capita in the United States, and possessed sophisticated corporation laws (see Wright 2014). Massachusetts was the center of several important manufacturing industries, especially textiles, and its manufacturing corporations were unusually large and widely held, relative to their peers in other states (see Scranton 1983).

Although most of the states' major manufacturing corporations were quite successful, a number of prominent figures in the Massachusetts' business community argued that the diffuse ownership of large corporations caused their governance, and operating results, to suffer. The issues they described often related closely to Problem 1. One investor named J .C. Ayer (1863) produced a pamphlet that claimed that the directors of these firms were paid excessively high salaries; hired their relatives for lucrative managerial positions; sold the corporations' finished products through mercantile firms they owned, and paid themselves excessive fees for those services; and 
concealed the effects of these practices from the shareholders. Ayer specifically ascribed these problems to the passivity of the firms' many small shareholders. He also argued that the directors, whose ownership stakes were quite low, perpetuated their control over their firms by soliciting proxy votes from the shareholders through duplicitous means, and, where necessary, by holding the annual meetings of companies with shareholders in common simultaneously, thereby preventing many shareholders from participating in more than one.

These problems were probably not acute or widespread enough to threaten investors' confidence in the governance of firms generally-there probably was no fullblown corporate governance crisis among these firms. However, in response to the complaints of shareholders, Massachusetts enacted at least two changes to its corporation laws in the 1850s and 1860s in order to help protect investors. One required corporations to make their books accessible to stockholders, and the other prohibited directors from voting more than 20 shares by proxy. Also, beginning in the 1870s, Massachusetts law required all of the state's manufacturing corporations to submit certificates of condition to the state government, which included basic balance sheet information, as well as the names of all stockholders and directors. These forms provide a window into the firms' ownership and governance.

Hilt (2014) analyzes these data. In 1870, the shares of 58 of the largest and most important manufacturing firms, and also 11 utilities, traded on the Boston Stock Exchange. Table 2 presents ownership data for the publicly traded companies from that year. Total paid-in capital for these firms was on average approximately $\$ 716,000$, equivalent to $\$ 13$ million in 2012 dollars. Median capital was $\$ 550,000$. Although the firms of 1870 were similar in size (as measured in paid-in capital) to New York's financial companies from 1826, they were much larger than manufacturing firms from 1826.

The data in Table 2 indicate that the 1870 manufacturing firms were quite widely held. Although the total numbers of shareholders were not that different from the 1826 New York corporations, their ownership was far less concentrated. The directors of the 1870 firms held only approximately $7 \%$ of the shares in their own names-complaints that the firms were managed by boards with small ownership stakes seem well-founded. 


\section{Table 2:}

Ownership of Boston Stock Exchange Traded

Manufacturing Firms and Utilities, 1870

\begin{tabular}{lcccccc}
\hline \hline & & \multicolumn{2}{c}{ \%Widely Held: } & & \\
& Shareholders & Cutoff & $\begin{array}{c}\text { To\% } \\
\text { Cutoff }\end{array}$ & $\begin{array}{c}\text { \% Owned } \\
\text { by Directors }\end{array}$ & $\begin{array}{c}\text { \% Controlled } \\
\text { by Directors }\end{array}$ \\
\hline All Boston Stock Exchange Corps & 184 & 80 & 98 & 6.8 & 8.7 \\
Above-median capital & 261 & 86 & 95 & 8.6 & 9.6 \\
Median or below & 110 & 75 & 100 & 5.3 & 8.2 \\
\hline Source: Author's calculations from data presented in Hilt(2013b).
\end{tabular}

The directors were in a position to vote approximately $2 \%$ more- these were nearly always shares held in family trusts where the director was a trustee-entitling them to about nine percent of the total votes. The governance issues related to Problem 1 that Berle and Means claimed were new among the enormous enterprises of the early twentieth century were in fact likely to have been present among industrial firms decades earlier than they claimed.

The Massachusetts corporations also exhibit a reliance on some of the same governance mechanisms as the New York corporations from 50 years earlier. Their ownership was overwhelmingly local (Davis 1958), and their boards of directors were dominated by wealthy and prominent men. Regular dividend payments were also regarded as critically important (McGouldrick 1968).

\section{Economic Transformation: Railroads, Big Business, and Bankers}

Over the course of the nineteenth century the development of railroads helped facilitate the economic integration of the different regions of the United States, which as we will see led to subsequent changes in the scale and organization of firms in other industries. However, the railroads themselves quickly grew into businesses of unprecedented size, and faced their own governance challenges. By the 1860s, several railroad corporations had been created with paid-in capitals of $\$ 20$ million or more; the capitalization of the largest of these enterprises was equal to approximately $40 \%$ of the total capital 
capitalization of all manufacturing enterprises traded on the Boston Stock Exchange at that time.

As with early nineteenth century banks, the creation of railroads and their operations were intimately tied to government policy. The entrepreneurs who founded railroad enterprises often allied themselves with political parties, purchased control of newspapers, or held public office. But the railroads' solutions to Problem 3 severely exacerbated Problem 2. Railroad insiders engaged in numerous forms of self-dealing or tunneling-including paying themselves exorbitant salaries, contracting with firms they controlled, borrowing their firm's securities for their own use, and issuing themselves shares of stock in exchange for worthless securities - and used their political influence to perpetuate their control. ${ }^{7}$ The construction of the transcontinental railroads in particular was subsidized by the federal government, and railroad insiders used those subsidies to enrich themselves personally at the expense of the public and the other shareholders. The directors of the Union Pacific, for example, created their own construction company, which they named Crédit Mobilier of America, and awarded it lucrative contracts to build the line and also distributed Crédit Mobilier shares to important congressmen. White (2012) chronicles this and many other such episodes among the transcontinentals. Other railroad insiders enriched themselves by coordinating the release of rumors or insider information with their own trading in their companies' stock; insider trading was not prohibited by law or regarded by jurists as a breach of directors' fiduciary responsibilities. ${ }^{8}$

In the 1860s and 1870s, these practices led to a series of corporate governance crises among major railroads. Addressing the problems exposed in these crises required substantial institutional innovations, which would have long-lasting implications for the governance of all major American corporations.

\footnotetext{
7 See Lamoreaux and Rosenthal (2006, pp.126--27) and the legal cases cited therein. It is perhaps worth noting that in this industry, tunneling occurred in both the literal and figurative sense.

8 Banerjee and Eckhard (2001) analyze insider trading associated with merger announcements
} 


\subsection{Railroads and Contests for Control}

The enormous cash flows that could be generated by a large railroad attracted the interest of politically powerful groups of investors who sought to dislodge sitting directors and obtain control so that they could enrich themselves. Incumbent managers of course resisted the attempts of such men to take over their enterprises, using whatever tactics they could. When a formidable group of investors sought to unseat equally powerful and well-connected directors, spectacular contests for controlrailroad "wars" -were the result. The competing sides each used their influence over the judiciary or members of the legislature in their campaigns, which often generated dozens of different lawsuits and even specific pieces of legislation.

These contests of control were important because they revealed the limits of states' legal protections of investors in an era of politically powerful investors-who were denoted by contemporaries as railroad barons. In the most egregious cases, laws intended to protect minority investors were utilized in ways that were the opposite of what their legislative authors intended: Rather than a powerless minority owner as presumed in the statute, major shareholders wielded these laws in their attacks on one another.

The nature of these conflicts is best illustrated with an example from New York, whose corrupt state government and judiciary during the Gilded Age created an ideal environment in which railroad barons could operate. Consider the Albany \& Susquehanna (A\&S) railroad, which J ay Gould attempted to take over in 1869. In the face of large stock purchases by Gould's men, the president of the A\&S "sold" to his allies on the board thousands of newly issued shares, lending them the required initial payment for the shares by issuing company bonds as collateral for a loan from a broker. The A\&S's president then hid the company's books in a nearby cemetery. Meanwhile Gould's attorneys used a provision of New York law that originated in the legal protections of investors enacted in 1828 (which were detailed above) to obtain an injunction from a judge affiliated with their political party-New York's Tammany Hall Democrats. The injunction suspended the president and most of the board from their offices. At the same time, the A\&S board obtained a competing injunction from a judge they could influence, vacating the original injunction, and suspending the one A\&S 
director loyal to Gould. Ultimately, both sides sued to have the railroad put in receivership, obtaining many more injunctions in the process. In an attempt to enforce their side's legal dicta, Gould's men raided the A\&S headquarters and, unable to locate the company's books, ultimately resorted to a campaign to physically take possession of the railroad. With a gang of hired thugs, Gould's men took over an A\&S train and rode down the line, taking control of stations as they proceeded. Some A\&S men responded by derailing the Gould-controlled train, provoking a physical battle between the two sides. Ultimately, the governor ordered the state's militia to take charge of the road, amid many further suits and countersuits, and efforts to bribe legislators to pass laws to legitimate each side's position. The details of this and several similarly outlandish episodes are presented in Adams and Adams (1871).

The confidence of railroad securities holders was shattered, and the financiers involved in distributing those railroad securities were appalled. One New York lawyer (George Templeton Strong; see Nevins and Thomas 1952, p. 264), observing a wave of railroad wars and the legal tactics employed, noted that "the abused machinery of the law is a terror to property owners." Ultimately, the situation was resolved when a brash young banker was elected vice president of the A\&S and presided over negotiations with a different railroad for an alliance that would keep the A\&S out of the reach of Gould, and also his rivals (Carosso 1987). That banker was the 32-year-old J . Pierpont Morgan, who later founded the investment bank bearing his name, and would make his reputation not just as a financier, but as an organizer and reorganizer of railroads and later, industrial giants.

In response to this and similar episodes, the NYSE in 1869 required the registration of securities by listed companies, making it more difficult for insiders to secretly issue huge amounts of stock, as the A\&S directors did. And efforts were made to reform the jurisdiction of New York's courts, to prevent rival factions from utilizing different judges in order to invalidate each other's injunctions.

But the most important solution to the problems posed by the railroad barons for investors and creditors was not legal in nature, for the railroad barons were more than powerful enough to subvert the law for their own ends. The solution that was ultimately found was for investment bankers to assume an active role in the governance of 
railroads. With their influence over access to capital, and with their incentives aligned with those of securities holders, investment banks sought to rein in the worst excesses of railroad managers (Carosso 1970; Redlich 1951). Firms such as J.P. Morgan \&Co. hired partners with elite social backgrounds and worked assiduously to maintain prestigious reputations (Pak 2013). The value of the firms' high social standing may have helped to signal that they would ensure that their clients would be free of scandals or unscrupulous management. Ultimately financiers began assume a significant role in the governance of industrial corporations as well.

\subsection{Bankers and Railroad Governance}

In the 1860s and 1870s, a relatively small number of investment banks capable of raising large sums of capital began to dominate the industry and establish relationships with prominent railroads. ${ }^{9}$ Initially, railroads' relationships with their bankers were arms-length in nature, and they might have used different banks over time. But eventually, following the scandals of the 1860s and 1870s, and particularly after the financial panic of 1893, major railroads established durable relationships with an investment bank (Carosso 1970). Those relationships were frequently cemented with board seats, as the partners of investment banks began to actively participate in the management and governance of railroads. In restructurings out of bankruptcy, a circumstance in which many of these relationships were first established, the shares of the railroad's stock were often placed in what was known as a voting trust, with the bankers as trustees, giving them total control over the enterprise for a specified period of time, usually several years.

9 These included Drexel, Morgan \& Co. (the predecessor to J .P. Morgan \& Co.), J \&W Seligman $\&$ Co., and Speyer \& Co., as well as the Boston firms Lee, Higginson \& Co., and Kidder, Peabody \& Co. (see Davis 1963 and Carosso 1970). Benmelech (2010) studies railroad capital structures. 
Table 3:

Ownership of NYSE-listed Railroads, 1910

\begin{tabular}{|c|c|c|c|c|c|}
\hline & \multirow[b]{2}{*}{$\begin{array}{c}\text { Total } \\
\text { Shareholders }\end{array}$} & \multicolumn{2}{|c|}{ \% Widely Held: } & \multirow{2}{*}{$\begin{array}{c}\text { \% Owned by } \\
\text { Investment } \\
\text { Banks }\end{array}$} & \multirow{2}{*}{$\begin{array}{c}\text { \% Owned by } \\
\text { Other } \\
\text { Railroads }\end{array}$} \\
\hline & & $\begin{array}{l}10 \% \\
\text { Cutoff }\end{array}$ & $\begin{array}{l}20 \% \\
\text { Cutoff }\end{array}$ & & \\
\hline NYSE - Listed Railroads & 14,928 & 32 & 44 & 5.9 & 22.8 \\
\hline Above-median capital & 17,724 & 48 & 65 & 2.8 & 15.8 \\
\hline Median or below & 3,740 & 16 & 25 & 8.9 & 29.6 \\
\hline
\end{tabular}

With their growing influence over railroad management, investment banking partnerships sought to curb practices in the industry that were harmful to the interests of the firms' creditors or led to instability. Competing railroads sometimes engaged in rate wars, and some entrepreneurs even constructed new routes that competed with successful railroads, with the intent of forcing the incumbent firms to buy them out on favorable terms. Although their power in some contexts was limited, investment bankers, particularly J .P. Morgan, actively worked to halt such practices.

Railroads were regulated by the Interstate Commerce Commission (ICC), created in1887, which compelled them to produce detailed annual financial reports. The ICC at times collected ownership data, and in 1910 they published data on the largest owners of major railroads. These data are presented in Table 3. At the time, the shares of 72 railroads were listed on the NYSE, and the average paid-in capital of the firms was $\$ 75.5$ million (equivalent to $\$ 1.9$ billion in 2012 dollars). Median capital was $\$ 47$ million.

The data in the table show that the ownership of these very large enterprises was rather concentrated, with relatively few of them widely held. Ownership by the board cannot be computed from the available data, but ownership by other railroads can, and this was often quite substantial. Often a parent railroad owned substantially all the stock of a smaller one but did not actually combine the assets of the two firms and dissolve the smaller one as a separate enterprise because of obstacles created by state corporation laws or railroad regulations, or because of the bond covenants of some of the companies. 


\subsection{Industrial Mergers: 1895--1904}

With the economy becoming more integrated, industrial firms in distant regions that once enjoyed some measure of local monopoly power found themselves in competition with one another. In the face of overcapacity and ruinous price cutting, firms in some industries began to establish cartels, sometimes through trade associations.

Horizontal mergers became common in the late 1890s, in response to conditions that both strengthened the impetus to combine and helped facilitate combination. The Sherman Antitrust Act of 1890 made collusive agreements among competitors illegal, but in its 1895 decision United States v. E. C. Knight Co., the Supreme Court held that mergers among competing manufacturing firms did not violate the Sherman Act, even if the merged firm controlled virtually all capacity in its industry. Around this time, the state of NewJ ersey liberalized its corporation laws, granting businesses incorporated in that state the right to operate in any other state and also the right to own shares in other corporations, thus creating a legal vehicle to facilitate mergers across state lines.

Between 1895 and 1904, an enormous number of industrial mergers occurred, most of which were incorporated in NewJ ersey (Lamoreaux 1985). The outcome of this wave of consolidation, which was the largest in American history when measured relative to GDP, was that for the first time large industrial corporations were created that dominated national markets. Thousands of firms such as those from the Boston Stock Exchange in the 1870s were rapidly combined into industrial giants. These industrial mergers typically resulted in consolidations in which the assets of the constituent companies were combined into a single new firm, rather than into a pyramidal holding company structure (Bonbright and Means 1932).

The investment bankers who organized and promoted mergers typically retained strong affiliations with the companies they created (see Moody 1904). As was the case with railroads, the participation of financiers was a critical element in the governance of these new enterprises. That is, investors were protected only to a limited extent by the law, and in much more important ways through the delegated monitoring that occurred with bankers participating on boards of directors. There were, of course, limits to the effectiveness of this mechanism. Some of these mergers failed quickly, and the 
promoters of some of the failed mergers resorted to accounting fraud and paid dividends out of their firms' capital, in order to quickly market their firms' securities to outsiders (Dewing 1914).

Berle and Means' (1932) study of the governance of the 200 then-largest enterprises in the United States includes many of the industrial giants created at the beginning of the twentieth century. They present a typology of different control structures, and document the extent of the separation of ownership from control among their sample firms. In their focus on control rights flowing from ownership stakes, however, Berle and Means omit any role for financiers, whose power may have been much greater than the votes their securities holdings entitled them to.

\section{The Twentieth Century}

\subsection{Progressive Backlash Against Bankers}

The role of financiers in creating and operating the new industrial giants, as well as major railroad systems, aroused considerable populist hostility. Like the so-called trusts that monopolized many industries, critics argued that a money trust consisting of a small number of New York financial institutions controlled access to finance, and dominated the American economy. ${ }^{10}$ The Panic of 1907, which began with runs on the shadow banks that had been heavily involved in financing major corporations (Frydman and Hilt forthcoming), further increased anti-banker sentiment. In 1912, the US House of Representatives authorized an investigation of the money trust by a committee headed by Representative Arsène P. Pujo (Pujo Committee, 1913). The committee's findings were popularized by progressive lawyer Louis Brandeis (1914) in a series of essays published as the book Other Peoples' Money and How the Bankers Use It. Brandeis argued that the money trust dominated many of the largest nonfinancial

\footnotetext{
10 The term trust is used in connection with monopoly in the United States because in the early 1880s Standard Oil and a few other early giants organized themselves in the legal form of the trust in order to circumvent the limitations of corporation laws. Standard Oil's trust agreement was ruled to be an illegal restraint of trade in 1892, and that firm, along with the others that had used the trust form, later reorganized as New J ersey corporations. Nonetheless the firms continued to be known as trusts.
} 
corporations, and used its position in numerous ways to enrich itself at the expense of ordinary investors.

Many found these arguments persuasive. A new sort of corporate governance crisis occurred-one of the most important mechanisms in the governance of American institutions was criticized not for being ineffective (although critics did make this argument), but for creating a politically unacceptable concentration of economic power. Thus, one of the solutions developed to address both Problem 1 and Problem 2 was seen as creating a different set of problems, and a wave of new regulations restricting the role of financiers followed.

At the federal level these new regulations included the Clayton Antitrust Act of 1914, which contained several provisions intended to curtail the role of bankers in corporate governance. At the state level, numerous so-called Blue Sky Laws were passed, which regulated the issuance of securities. ${ }^{11}$

Financial historians have expressed skepticism of the progressives' negative view of financiers' influence on nonfinancial corporations (Morrison and Wilhelm 2007). De Long (1991) and Cantillo Simon (1998) find the presence of J.P. Morgan partners on a firm's board to be associated with higher firm values, and Ramirez (1995) find them to be associated with better access to credit. Others have argued that the progressive view of the role of bankers significantly exaggerated their influence (Carosso 1970, Redlich 1951). In more recent work, Frydman and Hilt (2014) use a provision of the Clayton Act that compelled investment bankers sitting on railroad boards to resign or stop performing any underwriting services for their railroads to estimate the effects of investment bankers' roles in corporate governance. They find no evidence in support of the view that banker-directors harmed their client firms, and in fact following the implementation of the Act railroads with strong financial relationships with

\footnotetext{
${ }^{11}$ Although marketed as investor protections, Blue Sky Laws effectively protected local banks and savings institutions from competition from major securities underwriters (Macey and Miller 1991). However, Agrawal (2013) finds evidence that Blue Sky Laws actually did induce the riskiest class of securities issuers - mining companies - to increase dividends, and raised their market valuations.
} 
underwriters saw their investment rates, market values, and borrowing levels fall, and their borrowing costs rise.

\subsection{The Roaring Twenties}

Similarly to the 1990s, the 1920s in the United States witnessed relatively stable macroeconomic growth, technological innovations, and, of course, rapid increases in stock prices (White 2006). Ordinary households, many of which were induced to purchase financial assets for the first time during the Liberty Bond drives of World War I, began to participate in the stock market at ever higher rates (Mitchell 2007). And the number of listed companies increased substantially, as many innovative industrial firms were founded and went public.

Within these ebullient markets, changes occurred in the composition of public companies and in their governance. Many of the companies entering the market were incorporated not in New J ersey - which had been taken over by progressives who repealed the state's liberal corporation laws in 1917-but in Delaware, which had adopted the most liberal provisions of NewJ ersey's former statutes into its own laws and further liberalized them in several ways (Larcom 1937). Delaware's corporation laws eroded or eliminated some rights of stockholders that had been traditionally part of most states' corporation statutes, such as the preemptive rights of existing stockholders to participate in new share issuances, prohibitions against changes in the dividend requirements of certain classes of stock, and changes to the voting rights of shares (Seligman 1976).

Perhaps more importantly, in the 1920s pyramidal holding company structures emerged in the United States for the first time. Making use of Delaware's liberal corporation statutes, financiers and corporate promoters created some very large pyramidal groups that sometimes included hundreds of small operating companies (see Berle and Means 1932). The governance problems that can be created by such structures are well known, and recent research has ascribed substantial importance to those enterprises (e.g., Morck 2005b, Morck and Yeung 2005). 
But it remains true that pyramidal business groups never actually became common in the United States. ${ }^{12}$ They were almost never created among industrial companies (Bonbright and Means 1932), which were by far the dominant category of public firms and also the fastest-growing. ${ }^{13}$ Instead, they were prevalent mostly among utilities and to a lesser extent, among railroads. Among utilities, the complex holding company structures that emerged in the 1920s were created principally in response to local utilities regulation and public service commissions. Among railroads, the principal motive for their creation also appeared to be circumventing certain industry regulations. There were many family firms, but just as today, there were almost no family business groups organized as pyramidal organizations (Villalonga and Amit 2009).

\subsection{The Great Crash, Financial Crisis, and New Deal Reforms}

The Glass-Steagall Act, contained within the Banking Act of 1933, prohibited investment banks from engaging in deposit banking or holding directorships with commercial banks. The Securities Exchange Act of 1934 resulted in the creation of the SEC, required publicly traded companies to file periodic financial statements with the SEC, required company insiders to report their securities transactions and outlawed insider trading, and regulated proxy solicitations and the stock exchanges themselves. The registration and disclosure requirements of the Securities Exchange Act likely diminished the influence of investment banks in the certification of new issues. And the Glass-Steagall Act cut them off from important sources of clients, funding, and customers. Together, these changes likely diminished the role of investment banks in corporate governance. With their influence over access to capital markets weakened, their power and importance as voices in corporate management were likely also weakened.

\footnotetext{
12 In recent work, Kandel et al (2013) argue that pyramids were common and persistent. It is worth noting that a large fraction of the business groups identified in that paper are railroads and utilities.

${ }^{13}$ Holding company structures were indeed created in connection to industrials in the 1920s, but mostly to facilitate consolidations in which substantially all of the stock of the subsidiary companies was acquired by the parent, and in which there was only two "layers." These were therefore not pyramidal business groups in the definition of La Porta et al. (1999) or in the sense of extending control over subsidiary companies without proportionate ownership stakes. See Bonbright and Means (1932).
} 
Did the stronger disclosure requirements enforced by the SEC actually have any meaningful effects for shareholders? The NYSE had already required listed companies to produce annual financial reports, although it did not rigorously enforce any standards regarding the level of detail of those reports, and the disclosures did not include the identities and stakes held by large shareholders, the extent of ownership of the board, or the level of executive compensation. For companies listed on the NYSE, the requirements of the SEC should be considered much more detailed and more strictly enforced versions of the private rules they were already subject to. Careful empirical evidence by Simon (1989) indicates that following the creation of the SEC, the risks of new issues, as measured by the variance of returns over various time horizons, fell by statistically significant margins. Prior to the SEC, investors' expectations regarding new issues had not been biased - the average level of returns of new issues did not rise-but their forecast errors were larger. ${ }^{14}$

Morck (2005b) argues that New Deal changes in taxation policy, and in particular the imposition of taxes on intercorporate dividends, eliminated pyramidal business groups in the United States. Others are skeptical of this view and have claimed that tax changes had little effect on patterns of intercorporate ownership (Cheffins and Bank 2010). Certainly other New Deal regulations contributed to the decline of pyramids in the United States; the Public Utility Holding Company Act of 1935, for example, required that those enterprises simplify their structure and adopt stricter financial standards. But whatever the ultimate source of change, pyramidal groups were never commonplace.

\footnotetext{
${ }^{14}$ For new issues on other exchanges with lower standards and weaker disclosure requirements than the NYSE, Simon (1989) finds that average abnormal returns of new issues did in fact rise following the creation of the SEC-relative to the post-SEC era, initial public offerings had been systematically overpriced.
} 


\section{Conclusion: Insights from American History}

The business corporation has a long history in the United States. Over time, economic changes have given rise to successive generations of these enterprises, each operating within its own institutional context and facing its own governance problems. The solutions to those problems have sometimes been sought in legal innovations, and in other cases, institutional or market-based solutions emerged. And the changes made to address one set of problems in some cases may have made others worse, and in other cases were later rejected as politically unacceptable. What are the main insights from all this history, and what unresolved questions have been raised?

First, the evolution of the corporation in the United States has not followed a simple, linear trajectory, beginning with small, well-governed organizations in which shareholders participated actively and eventually ending with large, poorly governed organizations with absentee owners and opportunistic managers, as claimed by Berle and Means (1932). Early corporations were smaller than modern industrial firms, but they were quite large relative to the early economy. Perhaps more importantly, they sometimes suffered acute governance failures, often arising from the predations of controlling insiders.

Second, the United States has experienced significant episodes of what might be termed corporate governance crises-events that shatter investors' faith in corporate management and the governance institutions intended to protect their rights. Economic change brought about new enterprises, new business strategies, and new financial manipulations that rendered existing protections of investors ineffective. In some of these episodes, a resolution has been found not through legal change but through other institutional changes. For example, in the late nineteenth century, politically connected railroad barons capable of subverting the law emerged. They were restrained through greater participation by financiers in corporate governance, rather than through new legal reforms. In other cases, new legislation, not unlike Sarbanes-Oxley, has been enacted, as in 1820s New York.

Third, with the exception of utilities and to a lesser extent, railroads, pyramidal business groups have never been important in the United States. At times, wealthy 
families held sufficient stakes in sufficient numbers of major corporations to create such groups; however, they never cemented their control into pyramidal business group structures. This may have been due to the limitations of corporation laws at the time or to fears regarding antitrust prosecutions. Perhaps the right combination of capital market conditions, lax antitrust enforcement, and liberal corporation laws emerged only briefly in the 1920s. But it is also possible that wealthy families did not perceive any need to organize their holdings in the way that families in other countries do. The reason that the United States does not have pyramidal business groups today may be due to wealthy families not having felt they were necessary, rather than to the taxation of intercorporate dividends, as has been suggested (Morck 2005b).

Fourth, there is the question of legal origins. The common-law origins of America's legal system, it has been argued, has produced laws that protect the rights of investors well. But the history presented in this article has shown that many of the legal rights of shareholders did not come from English law or from judicial precedent but were written by state and federal legislators. When problems have been found in American corporate governance, legislators have responded in ways antithetical to common law: by writing codes. Some of those codes have been deeply flawed, and the role of common-law courts in adjudicating them has also been quite important. But the modern American legal system is a partially codified hybrid of common-law institutions and indigenous innovations. It is difficult to determine which has been more important in producing the beneficial characteristics of America's legal system today.

Finally, politics has been critically important in the evolution of the American corporation. Popular hostility to monopolies and the corrupting influence of political control over access to corporate charters led to the enactment of general incorporation laws that made the corporate form with strict regulations freely accessible. And antibanker sentiment has led to measures that constrained the role of financiers in the economy, and in nonfinancial corporations in particular. These deeply American sentiments have been quite influential in shaping the evolution of modern corporations and the governance problems they face, as well as the solutions available to address them. 


\section{References}

Acheson, Graeme, Campell, Gareth, Turner, J ohn D., and Nadia Vanteeva. 2014. "Corporate ownership and control in Victorian Britain." European Association for Banking and Financial History Papers, No. 14-02.

Adams, Charles F., and Henry Adams. 1871. Chapters of Erie, and Other Essays. Boston: J ames R. Osgood \& Co.

Agrawal, A. 2013. "The Impact of Investor Protection Law on Corporate Policy: Evidence from the Blue Sky Laws." J ournal of Financial Economics 107(2):417-435

Allen, F., and R. Michaely. 2003. "Payout Policy,” in Constantinides, Harris, and Stulz, ed: Handbook of the Economics of Finance. Amsterdam: North Holland.

Angell, J oseph K., and Samuel Ames. 1832. A Treatise on the Law of Private Corporations Aggregate. Boston: Hilliard, Gray, Little \& Wilkins.

Atack, J eremy, and Peter L. Rousseau. 1999. "Business Activity and the Boston Stock Market," Explorations in Economic History, 36(2): 144-79.

Ayer, J .C. 1863. Some of the Usages and Abuses in our Manufacturing Companies. Lowell: C M Langley \& Co.

Banerjee, Ajeyo and E. Woodrow Eckard. 2001. Why Regulate Insider Trading? Evidence from the First Great Merger Wave, 1897-1903. Am. Econ. Rev. 91(5):132949.

Baskin, J onathan B., and Paul J . Miranti. 1997. A History of Corporate Finance. New York: Cambridge University Press.

Becht, Marco, and J. Bradford Delong. 2005. "Why Has there been so Little Blockholding in America?" in Morck, ed., A History of Corporate Governance Around the World. Chicago: University of Chicago Press.

Bebchuck, Lucian A., and Assaf Hamdani. 2002. "Vigorous Race or Leisurely Walk: Reconsidering Competition Over Corporate Charters," Yale Law J ournal, 112: 553615.

Benmelech, Efraim. 2009. "Asset Salability and Debt Maturity: Evidence from Nineteenth-Century American Railroads," Review of Financial Studies, 22(4): 154584.

Benmelech, Efraim and Tobias Moskowitz. 2010. "The Political Economy of Financial Regulation: Evidence from U.S. State Usury Laws in the 19th Century." J ournal of Finance 65: 1029-73. 
Berle, Adolf A., and Gardiner C. Means. 1932. The Modern Corporation \& Private Property. New York: Harcourt, Brace.

Bertrand, Marianne, Mehta Paras, and Senhil Mullainathan. 2002. "Ferreting Out Tunneling: An Application To Indian Business Groups." Quarterly J ournal of Economics 117(1):121-148.

Bonbright, J ames C., and Gardiner C. Means. 1932. The Holding Company: Its Public Significance and its Regulation. New York: MoGraw-Hill.

Bodenhorn, Howard. 2006. "Bank Chartering and Political Corruption in Antebellum New York: Free Banking as Reform," in Goldin and Glaeser, eds., Corruption and Reform: Lesson's from America's Economic History. Chicago: University of Chicago Press.

Bodenhorn, Howard. 2011. "Federal and State Commercial Banking Policy in the Federalist Era and Beyond," in Irwin and Sylla, ed., Founding Choices: American Economic Policy in the 1790s. Chicago: University of Chicago Press.

Bodenhorn, Howard. 2012. "Voting Rights, Share Concentration and Leverage in Ninteenth-Century U.S. Banks." NBER Working Paper Series, number 17808.

Bodenhorn, Howard. 2013. "Large Block Shareholders, Institutional Investors, Boards of Directors and Bank Value in the Nineteenth Century, NBER Working Paper Series, number 18955.

Boyle, A. J . 1965. "The Minority Shareholder in the Nineteenth Century: A Study in Anglo-American Legal History," Modern Law Review, 28(3): 317-29.

Braggion, Fabio and Lyndon Moore. 2011. "Dividend Policies in and Unregulated Market: The London Stock Exchange, 1895-1905," Review of Financial Studies, 24(9): 2935-73.

Braggion, Fabio, and Lyndon Moore. 2013. "The economic benefits of political connections in late Victorian Britain." J ournal of Economic History, 73(1): 142-176.

Brandeis, Louis D. 1914. Other People's Money and How the Bankers Use it. New York: Frederick A Stokes Company.

Cantillo Simon, Miguel. 1998. "The Rise and Fall of Bank Control in the United States: 1890-1939," American Economic Review, 88 (5), 1077-93.

Carosso, Vincent. 1970. Investment Banking in America. Cambridge: Harvard University Press.

Carosso, Vincent. 1987. The Morgans: Private International Bankers, 1854-1913. Cambridge: Harvard University Press. 
Chandler, Alfred. 1977. The Visible Hand: The Managerial Revolution in American Business. Cambridge: Harvard University Press.

Cheffins, Brian R., and Steven A. Bank. 2010. "The Corporate Pyramid Fable," Business History Review, 84: 435-58.

Claessens, Stijn, and B. Burcin Yurtoglu. 2013. "Corporate Governance in Emerging Markets," Emerging Markets Review, 15: 1-33.

Coffee, J ohn C. 2001. "The Rise of Dispersed Ownership: The Roles of Law and the State in the Separation of Ownership and Control," Yale Law J ournal, 111 (1), 1-82.

David, Paul. 1967. "New Light on a Statistical Dark Age," American Economic Review, 57(2): 294-306.

Davis, J oseph S. 1917. Essays in the Earlier History of Corporations. Cambridge: Harvard University Press.

Davis, Lance E. 1958. "Stock Ownership in the Early New England Textile Industry" Business History Review 32: 204-222.

Davis, Lance E. 1963. "Capital Immobilities and Finance Capitalism: A Study of Economic Evolution in the United States, 1820-1920," Explorations in Entrepreneurial History, 2 (I): 88- 105.

Delong, J . Bradford. 1991. “Did J .P. Morgan's Men Add Value? A Historical Perspective on Financial Capitalism," in Peter Temin, ed. Inside the Business Enterprise. Chicago: University of Chicago Press.

Dewing, Arthur S. 1914. Corporate Promotions and Reorganizations. Cambridge: Harvard University Press.

Dodd, Edwin M. 1938. Lectures on the Growth of Corporate Structure in the United States with Special Reference to Governmental Regulation. Cleveland: Cleveland Bar Association.

Dodd, Edwin M. 1954. American Business Corporations Until 1860. Cambridge: Harvard University Press.

Dunlavy, Colleen A. 2004. "From Citizens to Plutocrats: Nineteenth-Century Shareholder Voting Rights and Theories of the Corporation." In Constructing Corporate America: History, Politics Culture, ed. Lipartito and Sicilia. Oxford: Oxford University Press.

Dunlavy, Colleen A. 2006. "Social Conceptions of the Corporation: Insights from the History of Shareholder Voting Rights." Washington \& Lee Law Review 63: 1347-87. 
Franks, Julian, Mayer, Colin, and Stefano Rossi. 2009. "Ownership: Evolution and Regulation," Review of Financial Studies, 22(10): 4009-50.

Freeman, Mark, Pearson, Robin, and J ames Taylor. 2012. Shareholder Democracies? Corporate Governance in Britain and Ireland Before 1850. Chicago: University of Chicago.

Frydman, Carola, and Eric Hilt. 2014. "Investment Banks as Corporate Monitors in the Early Twentieth Century United States.” Working paper, Northwestern University and Wellesley College.

Frydman, Carola and Eric Hilt. Forthcoming. "Economic Effects of Runs on Early Shadow Banks: Trust Companies and the Panic of 1907." J ournal of Political Economy.

Glaeser, Edward, and Andrei Shleifer. 2003. "Rise of the Regulatory State," J ournal of Economic Literature, 41(2): 401-25.

Gompers, Paul, Ishii, J oy, and Andrew Metrick. 2010. "Extreme Governance: An Analysis of Dual-Class Firms in the U.S." Review of Financial Studies 23: 1051-88.

Gower, L.C.B. 1956. "Some Contrasts Between British and American Corporation Law," Harvard Law Review, 69(8): 1369-1402.

Goodrich, Carter. 1960. Government Promotion of American Canals and Railroads. New York: Columbia University Press.

Guinnane, Timothy, Harris, Ron, Lamoreaux, Naomi, and J ean-Laurent Rosenthal. 2007. "Putting the Corporation in its Place," Enterprise \& Society, 8(3): 687-729.

Hammond, Bray. 1957. Banks and Politics in America From the Revolution to the Civil War. Princeton: Princeton University Press.

Hannah, Leslie. 2010. 'The 'Divorce' of Ownership From Control from 1900 Onwards: Calibrating Imagined Global Trends," Business History, 49(4): 404-38.

Hansmann, Henry, and Mariana Pargendler. 2010. "Voting Restrictions in 19th Century Corporations: Investor Protection or Consumer Protection?” Working paper, Yale Law School.

Harris, Ron. 2000. Industrializing English Law: Entrepreneurship and Business Organization, 1720-1844. New York: Cambridge University Press.

Henderson, Gerard C. 1918. The Position of Foreign Corporations in American Constitutional Law. Cambridge: Harvard University Press. 
Hilt, Eric. 2008. “When did Ownership Separate from Control? Corporate Governance in the Early Nineteenth Century." J ournal of Economic History 68: 645-85.

Hilt, Eric. 2009a. "Rogue Finance: The Life and Fire Insurance Company and the Panic of 1826," Business History Review, 83: 87-112.

Hilt, Eric. 2009b. "Wall Street's First Corporate Governance Crisis: The Conspiracy Trials of 1826," NBER Working Paper Series, number 14892.

Hilt, Eric. 2013. "Shareholder voting rights in early American corporations," Business History, 55(4): 620-635.

Hilt, Eric. 2014. "Corporate Governance and the Development of Manufacturing Enterprises in New England," NBER Working Paper Series, number 20096.

Hilt, Eric and J acqueline Valentine. 2012. "Democratic Dividends: Politics, Wealth and Stockholding in New York, 1790-1826.” J ournal of Economic History 72: 332-63.

Holderness, Clifford G., Randall S. Kroszner, and Dennis P. Sheehan. 1999. "Were the Good Old Days that Good? Changes in Managerial Stock Ownership Since the Great Depression." J ournal of Finance, 54: 435-69.

Hovenkamp, Herbert. 1991. Enterprise and American Law, 1836-1937. Cambridge: Harvard University Press.

Huebner, Solomon. 1903. "The Distribution of Stockholdings in American Railways," Annals of the American Academy of Political Science, 22(3), 63-78.

J ensen, Michael, and William Meckling. 1976. "Theory of the Firm: Managerial behavior, agency costs, and ownership structure," J ournal of Financial Economics, 3: 305-60.

Kandel Eugene, Kosenko, Konstantin, Morck, Randall, and Yishay Yafeh. 2013. "Business Groups in the United States: A Revised History of Corporate Ownership, Pyramids and Regulation, 1930-1950 NBER Working Paper Series, number 19691.

Kehl, Donald. 1939. "The Origin and Early Development of American Dividend Law," Harvard Law Review, 53(1): 36-67.

Kroszner, Randall S., and Raghuram G. Rajan. 1997. "Organization Structure and Credibility: Evidence from Commercial Bank Securities Activities Before the GlassSteagall Act," J ournal of Monetary Economics, 39 (4), 475-516.

Kroszner, Randall S., and Philip E. Strahan. 2001. "Bankers on Boards: Monitoring, Conflicts of Interest, and Lender Liability," J ournal of Financial Economics, 62 (3), 415-52. 
La Porta, Rafael, Lopez-de-Silanes, Florencio, Shleifer, Andrei and Robert W. Vishny. 1997. “Legal Determinants of External Finance.” J ournal of Finance, 52: 1131-50.

La Porta, Rafael, Lopez-de-Silanez, Florencio, Shleifer, Andrei, and Robert W. Vishny. 1998. “Law and Finance.” J ournal of Political Economy, 106: 1113-55.

La Porta, Rafael, Lopez-de-Silanes, Florencio, and Andrei Shleifer. 1999. “Corporate Ownership Around the World,"J ournal of Finance, 54(2), 471-517.

Lamoreaux, Naomi. 1985. The Great Merger Movement in American Business, 18951904. New York: Cambridge University Press.

Lamoreaux, Naomi. 1996. Insider Lending: Banks, Personal Connections and Economic Development in Industrial New England. New York: Cambridge University Press.

Lamoreaux, Naomi. 2009. "Scylla or Charybdis? Historical Reflections on Two Basic Problems of Corporate Governance," Business History Review, 83: 9-34.

Lamoreaux, Naomi, and J ean-Laurent Rosenthal. 2006. "Corporate Governance and Minority Shareholders in the United States Before the Great Depression," in Corruption and Reform: Lessons from America's Economic History, ed. Glaeser and Goldin. Chicago: University of Chicago Press.

Larcom, Russel C. 1937. The Delaware Corporation. Baltimore: J ohns Hopkins University Press.

Macey, J onathan, and Geoffrey Miller. 1991. “Origin of the Blue Sky Laws.” Texas Law Review 70(2):347-97

Mahoney, Paul G. 2003. "The Origins of Blue-Sky Laws: A Test of Competing Hypotheses,"J ournal of Law and Economics, 46: 229-51.

Martin, Albro. 1971. Enterprise Denied: Origins and Decline of the American Railroads, 1897-1917. New York: Columbia University Press.

McCraw, Thomas K. 1984. Prophets of Regulation. Cambridge: Belknap Press.

McGouldrick, Paul F. 1968. New England Textiles in the Nineteenth Century. Cambridge: Harvard University Press.

Mitchell, Lawrence E. 2007. The Speculation Economy: How Finance Triumphed Over Industry. San Francisco: Berrett-Koehler.

Moody, J ohn. 1904. The Truth About the Trusts. New York: Moody Publishing Company. 
Morck, Randall. 2005. “Title: How to Eliminate Pyramidal Business Groups: The Double Taxation of Inter-corporate Dividends and other Incisive Uses of Tax Policy," in Poterba, ed, Tax Policy and the Economy, 19: 135-179.

Morck, Randall (ed.). 2005. A History of Corporate Governance Around the World. Chicago: University of Chicago Press.

Morck, Randall. 2011. “Finance and Governance in Developing Countries,” NBER Working Paper, number 16870.

Morck, Randall, and Bernard Yeung. 2005. “Dividend Taxation and Corporate Governance,"J ournal of Economic Perspectives, 19(3): 163-180.

Morrison, Alan D., and William J. Wilhelm. 2007. Investment Banking: Institutions, Politics and Law. Oxford: Oxford University Press.

Musacchio, Aldo. 2009. Experiments in Financial Democracy: Corporate Governance and Financial Development in Brazil, 1882-1950. New York: Cambridge University Press.

Nevins, Allen and Milton H. Thomas, eds. 1952. The Diary of George Templeton Strong. 4 vols. New York: Macmillan.

North, Douglass C., Wallis, J ohn J ., And Barry R. Weingast. 2009. Violence and Social Orders: A Conceptual Framework for Interpreting Recorded Human History. New York: Cambridge.

Pak, Susie J . 2013. Gentlemen Bankers: The World of J .P. Morgan. Cambridge: Harvard University Press.

Porter, Glenn, and Harold C. Livesay. 1971. Merchants and Manufacturers: Studies in the Changing Structure of Nineteenth-Century Marketing. Baltimore: J ohns Hopkins University Press.

Pujo Committee. House Committee on Banking and Currency. 1913. Money Trust Investigation. Washington: Government Printing Office.

Ramirez, Carlos D. 1995. “Did J .P. Morgan's Men Add Liquidity? Corporate Investment, Cash Flow, and Financial Structure at the Turn of the Twentieth Century," J ournal of Finance, 50(2), 661-78.

Rajan, Raghuram G. and Luigi Zingales. 2003. "The Great Reversals: The Politics of Financial Development in the 20th Century.” J ournal of Financial Economics 69: 550 .

Redlich, Fritz. 1951. The Molding of American Banking: Men and Ideas. New York: Hafner Publishing Co. 
Roe, Mark. 1994. Strong Managers, Weak Owners: The Political Roots of American Corporate Finance. Princeton: Princeton University Press.

Scott, William R. 1912. The Constitution and Finance of English, Scottish, and Irish J oint-Stock Companies to 1720. Cambridge: The University Press.

Scranton, Philip. 1983. Proprietary Capitalism: The Textile Manufacture at Philadelphia, 1800-1885. New York: Cambridge University Press.

Seligman, J oel. 1976. "A Brief History of Delaware's General Corporation Law of 1899," Delaware J ournal of Corporate Law, 1(2): 249-87.

Seligman, J oel. 1982. The Transformation of Wall Street: A History of the Securities and Exchange Commission and Modern Corporate Finance. Boston: Houghton Mifflin.

Simon, Carol J . 1989. "The Effect of the 1933 Securities Act on Investor Information and the Performance of New Issues," American Economic Review, 79(3): 295-318.

Strouse, J ean. 2000. Morgan: American Financier. New York: HarperPerrenial.

Villalonga, Belen, and Raphael Amit. 2009. "How Are U.S. Family Firms Controlled?" Review of Financial Studies, 22(8): 3047-91.

Warshow, H.T. 1924. "The Distribution of Corporate Ownership in the United States," Quarterly J ournal of Economics, 39(1), 15-38.

Werner, Walter. 1986. "Corporate Law In Search of Its Future," Columbia Law Review, 81, 1610-1666.

White, Eugene N. 2006. "Bubbles and Busts: the 1990s in the Mirror of the 1920s," NBER Working Paper Series, number 12138.

White, Richard. 2012. Railroaded: The Transcontinentals and the Making of Modern America. New York: W.W. Norton.

Wright, Robert E. 2013. Corporation Nation. Philadelphia: University of Pennsylvania Press. 